Александра Јовић

Универзитет у Приштини

са привременим седиштем у Косовској Митровици

Филозофски факултет

Катедра за руски језик и књижевност

aleksandra.jovic@pr.ac.rs
УДК 811.161.1`367.626.8:811.163.41`367.626.8 https://doi.org/10.18485/slavistika.2021.25.2.22

Прегледни рад примљено 1.7.2021.

прихваћено за штампу 6.10.2021.

\title{
СТАТУС ПОВРАТНИХ (РЕФЛЕКСИВНИХ) ЗАМЕНИЦА У ГРАМАТИКАМА РУСКОГА И СРПСКОГ ЈЕЗИКА
}

Предмет овог рада је статус (пот)класе повратних (рефлексивних) заменица у традиционалним и новијим граматикама рускога и српскохрватског, односно српског језика. Иако је последњих деценија овој заменичкој врсти посвећен велики број теоријских радова, њена интерпретација у граматикама углавном има традиционалан карактер и у недовољној мери одражава резултате савремених истраживања. Доследнији описи овога језичког подсистема са ономасиолошког аспекта, употпуњени савременом језикословном терминологијом, допринели би ублажавању јаза између науке и њене школске интерпретације.

Кључне речи: граматика, рефлексивне заменице/заменичке речи, семасиолошки опис, ономасиолошки приступ.

The focus of this paper is placed on the (sub)class of reflexive pronouns in traditional and modern grammars of Russian and Serbo-Croatian, later Serbian. Although a substantial number of papers have presented studies of this class of pronouns in the last couple of decades, its interpretation in grammar books is somewhat traditional and it insufficiently reflects the results of modern research. More consistent descriptions of this language subsystem from the onomasiological aspect, supplemented by modern linguistic terminology, would contribute to bridging the gap between its examination in research and in schools.

Keywords: grammar, reflexive pronouns, semasiological description, onomasiological approach.

\section{СЕМАСИОЛОШКИ И ОНОМАСИОЛОШКИ ПРИСТУП ЈЕЗИКУ}

Анализом класе заменица, односно заменичких речи, особито поткласе повратних (рефлексивних) ${ }^{1}$ заменица, у релевантнијим граматикама ${ }^{2}$ рускога и српскохрватског, односно српског језика, ${ }^{3}$ може се утврдити приметна разлика у њиховом обиму и тумачењу. У граматикама семасиолошке оријентације, старијим и неким новим, ова заменичка врста махом се своди на заменицу себе/ се (рус. возвратное местоимение себя, возвратная частица, постфикс-ся/сь). Ређе се овој врсти придружује и присвојна заменица свој (рус. свой), као присвојноповратна (рус. притяжательно-возвратное местоимение), те узајамно-повратна

1 Термини су синонимични: први је карактеристичан за граматике, док се други готово искључиво среће у савременим лингвистичким проучавањима феномена рефлексивности (шире, као категорије, и уже, ограничено на заменичке речи или глаголе).

2 У анализу су укључене и нормативне и дескриптивне граматике, универзитетске и, махом, школске, синхронијског карактера, од којих неке садрже и обимније дијахронијске коментаре (реч је, дакле, о граматици као књизи, приручнику који садржи податке о граматичком устројству језика, о његовој структури и међусобним односима речи и конструкција).

${ }^{3}$ Након распада југословенске државе 1992. године језику је враћен првобитни назив „српски језик”. 
заменица један другога (рус. друг друга). Малобројне новије граматике у којима доминира ономасиолошки приступ језику приказују ову заменичку врсту нешто разуђенијом, чак прилично комплексном, придружујући јој и заменичке речи које се традиционално овамо (обично) не сврставају (сам, свој, по своме; pус. сам, свой, по-своему), налазећи ослонац у запажањима да функционалносемантичка категорија рефлексивности исказана заменичким речима може бити испољена експлицитно и имплицитно (као скривена категорија), те да би јој могло припасти и више места у лингвистичкој литератури, укључујући и контрастивно и типолошки оријентисана истраживања у славистици. ${ }^{4}$ П. Пипер, нпр., полазећи превасходно од словенске језичке грађе, констатује да су заменичка средства изражавања рефлексивности врло разноврсна, као и да се многе речи по својим семантичким и синтаксичким особинама могу сматрати заменицама иако се традиционално у њих не убрајају.

Досадашње интерпретације повратних (рефлексивних) заменица у школским граматикама показују да у њима углавном преовладава смер проучавања језичког система од форме ка смислу. И у овој врсти граматичких приручника, не само у универзитетским и научним граматикама, пожељна би била шира примена функционалног приступа језику, почев од ранијих етапа учења матерњег и страног језика. ${ }^{5}$ На проблем односа између школске и научне граматике посебно је, почетком XX века, указивао Александар Матвејевич Пешковски, критикујући раскид између лингвистике и њенога школског проучавања. ${ }^{6}$ И кроз призму анализе статуса рефлексивних заменица у граматикама рускога и српског језика показује се да теоријска достигнућа у лингвистици често недовољно налазе примену у пракси те да су одређене модификације у славистичкој граматичкој литератури, у складу са савременијим теоријским постигнућима, свакако пожељне и потребне. Као пример усаглашености са

${ }^{4} \mathrm{У}$ анализираним граматикама и граматичким приручницима упадљива је доминација традиционалног, формалнограматичког описа језичког система. Ономасиолошки приступ у тумачењу заменичких речи (па и осталих језичких подсистема) доследније је примењен у двема анализираним граматикама, в. Граматика руског језика: у поређењу са српском Предрага Пипера (Пипер 2005) и Нормативна граматика српског језика Предрага Пипера и Ивана Клајна (Пипер, Клајн 2013), док се у неким приручницима примењује спорадично.

${ }^{5}$ Као пример савременијег описа језичког система на овом нивоу могла би се навести Граматика српског језика за основну школу Душке Кликовац (2010), а штета је што повратне заменице нису нашле места у модерно и занимљиво конципираној Граматици руског језика за основне школе аутора Љубице Несторов и Богољуба Станковића (1994). При обради граматичког садржаја аутори полазе „од смисла преко синтаксичких модела до облика речи и конкретних исказа”. Путем индукције уопштавају се и систематизују језичке законитости, а језичка средства се групишу на основу смисла који се њима исказује.

${ }^{6}$ Да то није безначајно, потврђује и методичка пракса. „U konteksu savremenog pristupa nastavi stranih jezika, insistiranje na formi i strukturi, uz zanemarivanje funkcije i značenja gramatičke jedinice smatra se pogrešnim pristupom”, истиче Весна Пилиповић (Pilipović 2011: 193-200), и примећује да се „principi savremene nastave stranog jezika, i pored deklarativnih zalaganja, u nekim segmentima ne primenjuju u dovoljnoj meri” (Исто: 196). При обради граматичке грађе, ефикасно усвајање језика и ретенција наученог може се обезбедити једино стављањем (померањем) значења и функције језичких јединица у први план, уместо традиционалне фокусираности на њихову форму и структуру. 
новијим лингвистичким токовима може послужити Граматика руског језика: y поређељу са српском Предрага Пипера (Пипер 2005) и начин на који су у њој приказане не само заменичке него и друге врсте речи, њихове функционалносемантичке, морфосинтаксичке особености, граматичке категорије и особине (нпр. степеновање придева), са издвајањем граматичких, лексичко-граматичких и лексичких средстава у изражавању појединих функционално-семантичких категорија (в. трећи део књиге, у коме је примењен приступ језику од садржаја ка форми, 249-301). ${ }^{7}$

Чињеница је да у проучавању граматичких структура, у оквиру нових лингвистичких идеја и праваца последњих деценија XX века, ономасиолошко становиште („од смисла, семантике ка форми”) постаје све распрострањеније у односу на традиционално, семасиолошко („од форме ка значењу”). Испитујући функционисање језика као система, лингвисти полазе од функције језичке јединице и иду ка средству њеног изражавања, повезујући тако, на основу заједничког значења, формално најразличитије језичке појаве (Николић 2014: 12). Ипак, без обзира на све већу заступљеност ономасиолошког приступа у проучавању граматичких структура словенских језика, он још увек није доминантан и не примењује се довољно (Исто: 11$){ }^{8}$

\section{О ПРОУЧАВАЮИМА ЗАМЕНИЧКИХ РЕЧИ}

Озбиљније интересовање за комплексну класу заменичких речи везује се за шездесете године XX века и синтаксичка проучавања представника трансформационо-генеративне граматике. Међутим, с обзиром на чињеницу да су заменице неодвојиве од комуникације, говорног акта и контекста, поузданије одговоре о њиховој природи и начину функционисања донеће тек враћање живом језику у оквиру прагматике, корпусне и текстуалне лингвистике (Klajn 1985: $1-11)$.

Иако данас готово нико не доводи у питање постојање заменица као врсте речи, ${ }^{9}$ па ни употребу класичног термина (лат. pronomen, енг. pronoun, pyc. мeстоимение, итд.), и даље постоје разилажења у дефинисању опсега овог скупа: поједини аутори, држећи се морфолошког критеријума, у њега сврставају само

${ }^{7}$ Истина, ову граматику ипак најбоље разумеју студенти филологије, а њено читање је донекле отежано онима који немају адекватну лингвистичку припрему. То нас утолико више чини уверенима да су извесне иновације и у школским граматикама потребне већ на ранијим етапама овладавања граматичком структуром, примерено стеченим знањима, претходном искуству и когнитивним способностима ученика одређеног узраста.

${ }^{8}$ У терминологији Лава Владимировича Шчербе (1880-1944) традиционалне граматике носе епитет пасивних, док су граматике наглашенијег функционалног приступа језику оквалификоване као активне.

9 Традиционално поимање заменица као посебне врсте речи задржало се упркос бројним напоменама лингвиста о хетерогености и неодређености ове класе, па и повремено изношеном екстремном гледишту да оне као засебна врста речи и не постоје (в. Klajn 1985: 20-30). Насупрот последњем, издваја се, такође недовољно аргументовано, мишљење појединих лингвиста да заменице чине примарну и најисконскију врсту речи (в. Майтинская 1969: 27, 53, 283). 
променљиве заменице, док му присталице шире концепције и надилажења уско формалног приступа придружују и непроменљиве заменичке речи. ${ }^{10}$ Отуда и називна дистинкција: заменице, односно, шире, заменичке речи. Традиционално одређење заменица као речи које замењују (заступају) друге речи, у савременој лингвистичкој литератури готово да је сасвим истиснуто: већина аутора као примарну наводи њихову деиктичку или упућивачку функцију. ${ }^{11}$

Од шездесетих година прошлог века, и (пот)класа рефлексивних или повратних заменица постаје предмет синтаксичких проучавања. ${ }^{12}$ У последњих неколико деценија, пак, у фокус све већег броја лингвиста доспевају различите функционално-семантичке категорије (укључујући и рефлексивност), што представља основу за разраду типологије језика. Заменичкој рефлексивности, и, ређе, категорији рефлексивности, посвећују се бројни чланци, контрастивно и, знатно ређе, компаративно оријентисана истраживања, типолошка проучавања, дисертације. Отуда и наше интересовање за начин на који је ова тема интерпретирана у граматикама српскога и руског, па и других словенских језика.

\section{РЕФЛЕКСИВНЕ ЗАМЕНИЦЕ У ГРАМАТИКАМА СРПСКОГА И РУСКОГ ЈЕЗИКА}

Осим што имају велики лингводидактички значај, граматике представљају и врсту извора за лингвистичка истраживања: «Такие работы для нас ценны в основном по обработанному в них фактическому материалу; однако встречаются и грамматики, в которых раздел, посвященный местоимениям, по своему характеру приближается к специальным исследованиям» (Майтинская 1969: 23-24).

И у српској и у руској лингвистичкој традицији преовладава став да заменице, односно заменичке речи образују посебну врсту, што је својствено и свим овде наведеним граматикама. ${ }^{13}$ Видна разлика постоји у примени (доминантних) критеријума на основу којих су оне издвојене у посебну врсту речи, те, сходно томе, и у њиховом обиму, што се односи и на поткласу рефлексивних заменица.

Прве граматике на словенском терену одликују се формалнограматичким приступом, неретко и исцрпним дијахронијским коментарима, што се огледа и у приказу (рефлексивних) заменица. Ипак, и у традиционалним граматика-

10 «Чем строже выдерживается грамматический (прежде всего морфологический) принцип, тем меньше разрядов слов отнесено к местоимениям; чем больше применяется лексический принцип, тем более разнообразны разряды слов, включаемые в грамматических работах в раздел о местоимениях», примећује К. Ј. Мајтинска у фундаменталном раду Местоимения (Майтинская 1969: 34).

${ }^{11}$ Додуше, постоје и компромисна решења (хетерогене дефиниције), где се неке заменице одређују као речи које замењују, а друге - као деиктичке (упућивачке) речи.

${ }^{12}$ Код нас је ово поље отворила Милка Ивић радом „Један проблем словенске синтагматике осветљен трансформационом методом (граматичка улога морфеме се у српскохрватском језику)" (Ивић 1961: 137-151).

${ }^{13}$ Фокусирали смо се, углавном, на српске граматике у домаћој лингвистици, као и на руске граматике настале на руском и српском говорном подручју, уз кратак осврт на граматике других словенских језика настале у другој половини прошлог века и почетком 21. столећа. 
ма може се наићи на запажања о контекстуалној улози или функцији појединих језичких јединица, а каткад је у њима више места посвећено и плану употребе речи. У руској граматичарској традицији наглашенији је синтаксички критеријум, док је проучавање руског језика у српској средини обележено дугогодишњом применом контрастивног метода.

Писмениияасербскогаіезика, поговорупростоганароданаписана Вуком Стефановићем Сербиіанцеем у Виенни, 1814, у печатньи Г. Іоанна Шнирера, представља прву граматику српскога народног језика, сачињену са ослонцем на поглавље „О Етимологији или Художнословију” (тј. морфологији) црквенословенске граматике Аврама Мразовића ${ }^{14}$ (в. Ranđelović). У Вуковој подели заменица помиње се само једно „повраћателно мїестоимение” себе, са парадигмом која „неїма именителнога падежа". Формалнограматичким приступом одликује се и Gramatika $i$ stilistika hrvatskoga ili srpskoga književnog jezika Toma Maretića ${ }^{15}$ (1899), настала на језичкој грађи дела Вука Ст. Караџића и Ђура Даничића. Као повратна заменица помиње се једино себи, а за поједине специфичне падежне форме дају се и стилске напомене (,sasvijem izbaciti si... iz književnoga jezika... mislim da je pretjerano”, „ima oblika gdje je i si i sebi zališno i pogrješno”).

Россійская грамматика Михайла Ломоносова печатана в Санкт Петербургь при Императорской Академіи Наукь (1755) настала је на основу црквенословенске граматике Мелетија Смотрицког. ${ }^{16}$ Заменице се у њој третирају као помоћне и несамосталне речи, а подељене су на «первообразные» (у које аутор убраја и себя) и «производные» (које данас зовемо присвојнима). Себя се назива возвратительное местоимение, а прилично модерно звучи опаска да неке заменице «принимают на себя имен силу» (тј. могу бити супстантивизиране и адјективизиране, према савременом тумачењу): нпр. «он ему свой, то есть родственник, он самой обманщик, то есть великий обманщик, сам домой приехал, то есть господин».

Синхронијска Пространная русская грамматика, изданная Николаемъ Гречемъ, Санктпетербургъ (1827) представља покушај обједињавања идеја универзалне граматике са практичном граматиком. Посебну пажњу аутор је посветио лексичко-граматичким класама, као и граматичким својствима врста речи (тј. морфолошким категоријама у савременом схватању). Заменице представљају «промежуточное звено между знаменательными и служебными частями речи», «переход от части к частице». Аутор указује на њихова синтаксичка и творбена својства, на употребу у реченици. Као повратне, наводи заменице себя и свой. Кроз парадигму су дате и паралеле из других индоевропских

${ }^{14}$ Руководство къ славенстьй грамматіить во употребленїе славено-сербскихъ народныхх училичъ (Беч, 1794, прво издање).

15 Године 1850. у Бечу је постигнут књижевни договор српских и хрватских писаца, којим је постављен темељ заједничком српскохрватском језику. Назив „хрватски или српски језик” био је једно време у употреби након што је царски Беч забранио употребу глотонима ,југославенски језик”, установљеног одлуком хрватског сабора 1861. године.

16 Грамматіки Словенския правилное Сvнтагма, Евье, 1618-1619. Понекад се назива „Граматика Поликарпова” јер је 1721. штампана у Москви уз измене и допуне које је унео Теодор Поликарпов-Орлов. 
језика, а придевска заменица свой доводи се у етимолошку везу са именичком заменицом себя. ${ }^{17}$

Истовремено нормативна и дескриптивна, Русская грамматика Александра Востокова, по начертанію его же Грамиатики полнье изложенная, изданіе треmіе, С. Петербургъ: Типографія Императорской Россійской Академіи (1838) представља наставак национално оријентисане руске граматичке науке чије је темеље поставио Ломоносов, што се првенствено огледа у лаконичности излагања, тежњи да се шире обухвати живи језик и укаже на одлике појединих стилова. Заменице се дефинишу на традиционалан начин: «... разряд слов, заменяющий и дополняющий имена...». У групи личних заменица налази се и «возвратное местоимение себя» («показывает, что действие... обращено на самого действователя»).

Дијахронијске напомене чине посебну вредност Граматике руског језика (II Облищи) Радована Кошутића (1918/1984). Врсте речи Кошутић анализира пре свега са морфолошког аспекта, илуструјући језичке појаве минималним бројем примера, што важи и за повратну заменицу себя и присвојно-повратну заменицу свой. Пажњу савременог читаоца привући ће опаска о употреби заменице свој у значењу „својта”, тј. о могућности њене супстантивације.

Од друге половине XX века, у граматикама се, и поред њихове доминантне семасиолошке оријентације, уочавају елементи наглашенијег функционалног приступа језику. Дескриптивна и прескриптивна граматика Савремени српскохрватски језик (Граматички системи и књижевнојезичка норма) Михаила Стевановића, у два тома: I - Фонетика и морфологија (1964) и II Синтакса (1969), у групу личних именичких заменица убраја повратну заменицу себе, $c e$, „...која се ... употребљава за свако граматичко лице ..., увек када појмом субјекта у реченици треба означити неки однос према њему самом". Аутор скреће пажњу и на нарушавање књижевнојезичке норме употребом личних заменица трећег лица уместо повратне.

Грамматика русского языка, том I - Фонетика и Морфология, у редакцији В. В. Виноградова (1960) као повратне квалификује две заменице: себя и свой. «Возвратное местоимение себя не имеет ... форм именительного падежа, ... выступает в предложении в роли дополнения, обозначая объект, который является одновременно субъектом производимого им действия». Свой као «возвратное притяжательное местоимение...указывает на принадлежность предмета субъекту речи», а издвојено је и опште значење припадности, својине, када се употребљава ван односа према одређеном лицу: Своя ноша не тянет.

Синхронијска Граматика руског језика (фонетика и морфологија) Вере Николић (1969), са елементима контрастирања са српскохрватским језиком, велику пажњу поклања прагматичком аспекту (примери су махом узимани из говорног језика). Заменице се одређују као речи које упућују на предмете и лица или на њихове особине. Како је морфолошки критеријум ипак преовлађујући,

\footnotetext{
${ }_{17}$ Уп. Petar Skok, Etimologijski rječnik hrvatskoga ili srpskoga jezika I-IV (1971-1973): преко заједничког ие. корена *-sue: suo-, са превојем вокала, аутор повезује наглашену рефлексивну заменицу себе са лексемом свој, као и речима: свекрва, слобода, сват, сестра, посјета и др. („Ie. refleksivni korjen *-sue: suo- igra veliku ulogu u terminologiji ie. i praslav. agnatske/velike porodice..., i možda u terminologiji plemenskih naziva i pripadništva plemenu").
} 
заменички прилози су као непроменљиве речи прибројани прилозима. Повратне заменице не чине засебну поткласу, него се као једина наводи повратна заменица себя.

Ruska gramatika u poređenju sa srpskohrvatskom Бранка Тошовића (Tošović 1988) контрастивног је карактера. Класа заменица представљена је више у духу лингвистичке традиције: као повратна помиње се заменица себя, која „ukazuje na lice (predmet) koje predstavlja objekat svoje sopstvene radnje”. За заменицу друг друга са „uzajamno-povratnim značenjem” српскохрватски еквивалент је „složeni oblik", посебан за сваки род и број.

Донекле се подудара са Тошовићевим приказ повратних заменица у граматици под насловом Русская грамматика у редакцији Н. Ј. Шведове (1980). И овде се у групи повратних заменица (возвратные местоимения) помиње заменица себя, рашчлањују се њене семантичке, морфолошке и синтаксичке карактеристике, наводи се и њено секундарно, уопштено-лично значење, а поменуто је и «взаимно-возвратное местоимение друг друга», са свим морфосинтаксичким одликама.

За Граматику српскога језика Живојина Станојчића и Љубомира Поповића (1992) карактеристични су новији приступи језику. Заменице се, нпр., дефинишу као деиктичке или упућивачке речи. Заменица себе, се назива се личном заменицом сваког лица и укратко се разматра са морфосинтаксичког и прагматичког аспекта.

Контрастивним приступом језичким чињеницама са неопходним компаративно-историјским коментарима одликује се Gramatika ruskog jezika Радмила Маројевића (Marojević 1998), окарактерисана у предговору аутора као „funkcionalna gramatika u kojoj se... gramatički sistem ruskog jezika opisuje ne samo sa paradigmatskog nego i sa sintagmatskog aspekta...". На функционални карактер граматике указује и употреба термина заменичке речи. Заменички прилози по граматичким одликама (непроменљивост, синтаксичка функција адвербијала) спадају у категорију прилога, а по значењу припадају заменичким речима, у које аутор убраја још и заменичке бројеве, именичке и придевске заменице. Обе последње групе аутор сврстава у заменице у ужем смислу (местоимение). У оквиру именичких личних заменица издвајају се „lične zamenice svakog lica ili povratne zamenice, koje nikada ne mogu biti subjekat u rečenici, pa zato nemaju nominativ": себя, са истим основним значењем као српска заменица себе, те заменица друг друга са узајамно-повратним значењем, на чије се могућности транспоновања у српском језику указује на примерима.

Практична граматика руског језика (фонетика и морфологија) Надежде Лаиновић-Стојановић (2002) даје хетерогену дефиницију заменичких речи: „Заменице су врста речи које замењују именице и придеве или се њима указује на лица, предмете и сл." Као повратна заменица наводи се себя, са својим морфосинтаксичким особинама и енклитичким обликом у саставу повратних глагола. Нешто више је речено о употреби (конструкције с присвојним значењем и устаљени изрази), уз навођење српских еквивалената. Као у већини савремених граматика, и овде се говори о широј групи заменица названој заменичким речима (местоименные слова), које обухватају и заменичке бројеве и заменич- 
ке прилоге, тј. и непроменљиве речи. Морфолошке одлике речи нису, дакле, у првом плану. ${ }^{18}$

Обе словенске средине, и руска и српска, могу се похвалити и модерно конципираним школским граматикама, што се ипак није одразило на обухват класе (рефлексивних) заменица у њима. Русский язык: краткий теоретический курс для школьников Ј. И. Литневске (Литневская 2002) представља приручник у коме су нашли одраз и неки савремени лингвистички погледи. Истиче се, нпр., да има различитих класификација речи на врсте, обично изведених само на основу једног критеријума (семантичког, морфолошког или синтаксичког), док се дата школска класификација базира на свим трима основама. Заменице су дефинисане као «самостоятельная незнаменательная часть речи, которая указывает на предметы, признаки или количества, но не называет их». Само је једна заменица у оквиру поделе по семантичком критеријуму наведена као повратна: себя. ${ }^{19}$ Граматика српског језика за основну школу Душке Кликовац (2010) излаже градиво о заменицама на начин који није уобичајен за традиционалне школске граматике: у анализи су обједињени функционално-семантички, формални (морфолошки), синтаксички и прагматички критеријум. ${ }^{20}$ Заменице се дефинишу као речи које упућују на неки предмет, биће или појаву, или на неку њихову особину. Лична заменица за свако лице је себе/се, која „упућује на појам означен субјектом”, што је илустровано бројним примерима са коментарима.

И поред све сажетости популарне Gramatike srpskog jezika za strance Ивана Клајна (Klajn 2006), у њој је много пажње посвећено заменицама будући да се аутор и теоријски доста бавио проблемом ове врсте речи. ${ }^{21}$ Полазећи од уверења

${ }^{18}$ И у овој граматици примењен је упоредни метод: руски језик се, колико то карактер приручника дозвољава, пореди са српским на синхронијском плану, а примери којима се илуструје употреба језичких јединица нису ограничени само на књижевноуметнички стил.

19 Ауторка се, очито, ослања на новија проучавања заменица: «... местоимение как часть речи не обладает грамматическим единством и выделено на основании своей отсылочной функции». Деиктичка функција заменичких речи (термин сведочи о широј концепцији заменица) даље се разрађује: оне не именују предмете, особине, количине, околности, него указују на њих, упућујући нас или на ванјезичку стварност, говорну ситуацију, или на претходни или наредни, потоњи, (кон)текст, што се илуструје примерима. Последња напомена звучи као парафраза запажања о говорном чину, хиперсинтакси, анафори, катафори, антецеденту. Ипак, ауторка подсећа и на лингвистичку традицију, коју следи у свом коначном опису и омеђивању класе заменица: руководећи се морфолошким критеријумом, заменичке прилоге прибројава прилозима као врсти речи («Местоименные наречия описываются нами как незнаменательный разряд наречий»).

${ }^{20}$ И напомена о заменичким прилозима представља добар пример како се школски граматички приручник може осавременити комплекснијим лингвистичким приступом: „У оквиру прилога може се издвојити и једна група која је блиска заменицама и назива се заменички прилози". Наводе се њихова прилошка значења и службе у реченици, као и формални показатељ (непроменљивост). Потом се указује на функционални аспект, по коме су блиски заменицама: могу бити упућивачке речи, везане и невезане за учеснике у комуникацији. Истина, у систему врста речи они су ипак прибројани прилозима, а не заменицама, с обзиром на своја морфолошка обележја (што је ауторка можда сматрала примеренијим с обзиром на основношколски ниво граматике).

$$
{ }^{21} \text { В., пре свега, његов фундаментални рад O funkciji i prirodi zamenica (1985). }
$$


да се „sve iole ozbiljne naučne gramatike pojedinih jezika... služe eklektičkom metodom" (Klajn 1985: 7), аутор у анализу укључује функционално-семантички, морфолошки, синтаксички и прагматички критеријум. Велики број примера употребе (правилне и неправилне) образлаже се чињеницом да су „zamenice... vezane za komunikaciju, za situaciju govora više nego ma koja druga vrsta reči”. У оквиру поделе по семантичком критеријуму издвојена је и повратна заменица себе, чију морфолошку специфичност, одсуство номинатива или облика за субјекат, аутор образлаже тиме што се она увек односи на субјекат реченице у којој се налази. Као присвојно-повратна именује се заменица свој јер означава „pripadnost subjektu rečenice u kojoj se nalazi”.

Предраг Пипер је, као аутор и у коауторству са Иваном Клајном, задужио славистику двема значајним граматикама у духу савремених лингвистичких погледа. Његова Граматика руског језика у поређењу са српском (2005) представља приручник доминантно ономасиолошке оријентације, у коме су обједињена савремена искуства лингвистичке русистике и добра традиција проучавања руског језика код Срба, како се апострофира у предговору. Приручник исцрпно описује и објашњава функционално-семантичка и морфосинтаксичка обележја повратних (рефлексивних) заменица, укључујући и њихов прагматички аспект. Ова заменичка врста приказана је као врло развијена и разуђена (пот)класа (себя, друг друга, друг дружки, один другого, свой, по-своему, сам), што има теоријску подлогу у бројним радовима аутора. Посебно је значајно што је граматика контрастивна: руски језички систем пореди се са српским. Основна повратна заменица, себя, „у реченици има улогу директног или индиректног објекта, а употребљава се онда када је семантички субјекат реченице истовремено у њој и семантички објекат". Помиње се и узајамно-повратна заменица друг друга (и могућност исказивања узајамности конструкцијом один другого), као и „социјативно-повратна заменица” сам. Аутор се бави и специфичностима употребе повратно-присвојне заменице свой у партиципским конструкцијама и безличним реченицама, наглашава се могућност њене замене присвојном заменицом првог или другог лица (наш, ваш) „када се наглашава припадност групи лица", а истичу се и контексти када се заменица свой не употребљава, када наглашава однос припадања наспрам могућности неприпадања, када се употребљава као антоним речи чужсой (туђ), када је употребљена у уопштеноприсвојном значењу. Нормативна граматика српског језика П. Пипера и И. Клајна (2013), капитално дело значајно за неговање језичке културе, одликује се наглашено функционалним приступом: језичке јединице се, укључујући и заменичке речи, посматрају са ономасиолошког аспекта, те се и неке именице (чињеница и др.) и придеви (нпр. дати), по својим функционално-семантичким обележјима у одређеним контекстима, прикључују класи заменица (као прономинализоване лексеме). У тумачењу језичких појава аутори нису занемарили ни добру лингвистичку традицију (уважавање формалнограматичког или морфолошког критеријума). Много пажње посвећено је и прагматичком аспекту заменичких речи, што је, све скупа, омогућило да опис и дефинисање књижевнојезичке норме везане за њихову употребу буду много исцрпнији него у осталим граматикама које смо за потребе овога рада имали прилике да размо- 
тримо. $^{22}$ Заменице су дефинисане као врста речи са категоријалним значењима и деиктичком функцијом у чијем систему језгро чине именичке заменице, непроменљиве заменичке речи представљају граничне случајеве, а помињу се и прелазни случајеви међу семантичким класама заменица (свој и сам), док је лексема туђ са значењем „не свој” смештена на периферији заменичког система. Све повратне заменичке речи и изрази, себе, сам, свој, један другог (са значењем реципрочности), ${ }^{23}$ по своме (као „начинско-повратни заменички израз”), упућују на лице које је реченични субјекат. С обзиром на нормативни карактер граматике, јасно је и детаљно издиференцирана употреба лексеме свој и присвојне заменице трећег лица. Наводе се и синтаксичке специфичности заменице свој у партиципским конструкцијама, случаји када је лексикализована, са ослабљеним заменичким својствима, када се може заменити присвојном заменицом првог, другог и трећег лица, а када изоставити итд.

Иако је концепција граматичких приручника одређена и лингводидактичким околностима (ниво, циљ, матерњи или страни језик итд.), па функционални приступ не може бити увек једнако заступљен, славистичка граматичка литература ипак не иде увек у корак са савременим лингвистичким токовима. Зато малобројне приказане граматике чије је тежиште на проучавању значења и функције језичких јединица представљају значајно достигнуће. У њима, међутим, нема раскида са добрим тековинама традиције, него се два комплементарна приступа граматици и језику (од садржаја ка форми и од форме ка садржају) примењују заједно како би се потпуније сагледала целина граматичког система и правила његовог функционисања (в. Пипер и др. 2005: 575). Осветљен на тај начин (Пипер 2005, Пипер, Клајн 2013), управо систем заменица, као и подсистем рефлексивних заменичких речи, у свој својој морфолошкој, творбеној, синтаксичкој и функционално-семантичкој разноврсности, ${ }^{24}$ омогућава да се увиде предности таквог сагледавања језичких чињеница. То би у будућности могло водити и обогаћивању граматичких приручника потребним терминима (анафора, катафора, антецедент, референција итд.) са адек-

${ }^{22}$ Овако изнијансиран приступ заменицама свакако се може објаснити и чињеницом да су аутори, поготово П. Пипер, знатан део свог опуса посветили расветљавању управо ове врсте речи, в. књигу И. Клајна O funkciji i prirodi zamenica (претходна напомена), докторску дисертацију П. Пипера Zamenički prilozi (gramatički status i semantički tipovi) (1983), Заменички прилози у српскохрватском, руском и пољском језику (семантичка студија) (1988), као и знатан део Пиперовог опуса: „Pronomina reflexiva у српскохрватском језику (у поређењу са руским)” (1984-1985), „Реципрочност и рефлексивност у словенским језицима” (1986), „О морфолошкој класификацији заменица у руском језику: у поређењу са српскохрватским (парадигматски аспект)" (1986) итд.

23 У складу са приступом језику у коме се полази од смисла, помиње се и могућност исказивања узајамности другим језичким средствима, нпр. реципрочно-повратним глаголима, префиксалним средствима, заменицама узајамно, међусобно итд.

${ }^{24}$ Разлике у флексији и типу деклинације, морфолошким категоријама, начину творбе, синтаксичкој функцији (нпр. објекта, адвербијала, атрибута код рефлексивних заменица), издвајање неколико подврста по морфосинтаксичом критеријуму (именичке, придевске заменице, заменички прилози и бројеви), анафорска функција рефлексивних заменица (са свом сложеношћу њихових антецедената), деиктичка функција, својствена, пре свега, заменицама првога и другог лица (али и непостојање оштре границе између анафоре и деиксе). 
ватним тумачењима, ${ }^{25}$ а у средњошколским и универзитетским граматикама могла би наћи место и класификација подсистема рефлексивних заменица на семантичко-синтаксичкој основи П. Пипера. ${ }^{26}$

Случаји супстандардне употребе личне заменице трећег лица (ређе првог и другог) уместо рефлексивне у савременом српском језику, као и потешкоће у употреби заменичког рефлексива код носилаца руског језика (неретко и у сложеној реченици научног стила), захтевају, с обзиром на фреквентност јављања, исцрпнију анализу у граматикама двају језика, не само у онима које су профилисане као нормативне.

\section{Цитирана литература}

Klajn, Ivan. O funkciji i prirodi zamenica. Milka Ivić (red.). Beograd: Institut za srpskohrvatski jezik, 1985.

Майтинская, Клара Е. Местоимения в языках разных систем. Москва: Наука, 1969.

[Majtinskaâ, Klara E. Mestoimeniâ v âzykah raznyh sistem. Moskva: Nauka, 1969]

Николић, Марина. Категорија степена у српском језику: сложена реченица. Београд: Институт за српски језик САНУ, 2014.

[Nikolić, Marina. Kategorija stepena u srpskom jeziku: složena rečenica. Beograd: Institut za srpski jezik SANU, 2014]

Пипер, Предраг. „Pronomina reflexiva у српскохрватском језику (у поређењу са руским)“. Зборник Матице српске за филологију и лингвистику XXVII-XXVIII, 1984-1985: 633-639.

[Piper, Predrag. „Pronomina reflexiva u srpskohrvatskom jeziku (u poređenju sa ruskim)“. Zbornik Matice srpske za filologiju i lingvistiku XXVII-XXVIII, 1984-1985: 633-639]

Пипер, Предраг. „Семантичке категорије у простој реченици: синтаксичка семантика“. [У:] Пипер,

Предраг, Ивана Антонић, Владислава Ружић, Срето Танасић, Људмила Поповић, Бранко Тошовић. Синтакса савременога српског језика - проста реченица. Милка Ивић (ред.). Београд: Институт за српски језик САНУ, Београдска књига, Матица српска, 2005.

[Piper, Predrag. „Semantičke kategorije u prostoj rečenici: sintaksička semantika““. [U:] Piper, Predrag, Ivana Antonić, Vladislava Ružić, Sreto Tanasić, Ljudmila Popović, Branko Tošović. Sintaksa savremenoga srpskog jezika - prosta rečenica. Milka Ivić (red.). Beograd: Institut za srpski jezik SANU, Beogradska knjiga, Matica srpska, 2005]

Pilipović, Vesna. „Dugoročnost efekata savremenog pristupa obradi gramatičke građe“. [U:] Točanac, Dušanka, Snežana Gudurić (prir.) Primenjena lingvistika danas -

${ }^{25}$ Наговештај томе видимо у школској граматици Литневске (Литневская 2002), која доста детаљно образлаже појам деиксе и деиктичке функције.

${ }^{26}$ Рефлексивне заменице спољашње карактеристике (општерефлексивна заменица себе и заменице са посебним рефлексивним значењима: социјативне, посесивне, компаративне) и рефлексивне заменице унутрашње карактеристике (заменице истоветности односа: социјативне, посесивне, компаративне и заменице различитости односа: реципрочне и нереципрочне: социјативне, посесивне, компаративне) (в. детаљније Пипер 1984-1985: 633-639). 
između teorije i prakse. Novi Sad: Društvo za primenjenu lingvistiku Srbije, Filozofski fakultet u Novom Sadu, Beograd: Filološki fakultet u Beogradu, 2011, 193-203.

Ranđelović, Ana. „Vuk kao terminolog (prvi i drugi deo)““. < https:// jezikofil.rs//vukkao-terminolog> 1.11.2021.

\section{Извори}

Белоусов, Вячеслав Н., Ирина И. Ковтунова, Ирина Н. Кручинина. Русская грамматика. Наталия Ю. Шведова, Владимир В. Лопатин (ред.). Москва: Русский язык, 1990.

[Belousov, Vâčeslav N., Irina I. Kovtunova, Irina N. Kručinina. Russkaâ grammatika. Nataliâ. Û. Švedova, Vladimir V. Lopatin (red.). Moskva: Russkij âzyk, 1990]

Виноградов, Виктор В. (ред.). Грамматика русского языка, том I,

Фонетика и Морфология. Москва: Академия Наук СССР, Институт русского языка, 1960.

[Vinogradov, Viktor V. (red.). Grammatika russkogo âzyka, tom I, Fonetika i Morfologiâ. Moskva: Akademiâ nauk SSSR, Institut russkogo âzyka, 1960]Востоков, Александр X. Русская грамматика Александра Востокова, по начертанію его же Грамматики полнъе изложенная, изданіе третіе. С. Петербургъ, Типографія Императорской Россійской Академіи, 1838.

[Vostokov, Aleksandr H. Russkaâ grammatika Aleksandra Vostokova, po načertaniû ego že Grammatiki polneê izložennaâ, izdanie tretie. S. Peterburg, Tipografiâ Imperatorskoj Rossijskoj Akademii, 1838]

Греч, Николай И. Пространная русская грамматика, изданная Николаемъ Гречемъ, Том первый, Санктпетербургъ, 1827.

[Greč, Nikolaj I. Prostrannaâ russkaâ grammatika, izdannaâ Nikolaem Grečem, Tom pervyj, Sanktpeterburg, 1827]

Караџић, Вук Ст. Писменица сербскога іезика, по говору простога народа написана Вуком Стефановићем Сербиіанцем, у Виенни, 1814. у печатньи Г. Іоанна Шнирера

[Karadžić, Vuk St. Pismenica serbskoga iezika, po govoru prostoga naroda napisana Vukom Stefanovićem Serbiiancem, u Vienni, 1814. u pečatnji G. Ioanna Šnirera]

Кликовац, Душка. Граматика српског језика за основну школу. Београд: Креативни центар, 2010.

[Duška Klikovac. Gramatika srpskog jezika za osnovnu školu. Beograd: Kreativni centar, 2010]

Лаиновић-Стојановић, Надежда. Граматика руског језика (фонетика и морфологија). Ниш: Филозофски факултет 2002.

[Lainović-Stojanović, Nadežda. Praktična gramatika ruskog jezika (fonetika i morfologija). Niš: Filozofski fakultet, 2002]

Литневская, Елена И. Русский язык: краткий теоретический курс для школьников. Москва: МГУ; БСМП ЭЛЕКС - Альфа, 2002. <https://Studfiles.net и gramota.tv/ biblio/readingroom/textbooks/author/litnevskaya

[Litnevskaâ, Elena I. Russkij âzyk: kratkij teoretičeskij kurs dl'â škol'nikov. Moskva: MGU; BSMP ELEKS Al'fa, 2002. <https://Studfiles.net и gramota.tv/biblio/ readingroom/textbooks/author/litnevskaya]Ломоносов, Михаил В. Россійская грамматика Михайла Ломоносова печатана в Санкт Петербургь при Императорской 
Академіи Наукь 1755 года

[Lomonosov, Mihail V. Rossijskaâ grammatika Mihajla Lomonosova pečatana v Sankt Peterburge pri Imperatorskoj Akademii Nauk 1755 goda]

Несторов, Љубица, Богољуб Станковић. Граматика руског језика. Београд: ЗУНС, 1994.

[Nestorov, Ljubica, Bogoljub Stanković: Gramatika ruskog jezika. Beograd: ZUNS, 1994]

Николић, Вера. Граматика руског језика (фонетика и морфологија). Београд: ЗУНС, 1969 (четврто издање)

[Nikolić, Vera. Gramatika ruskog jezika (fonetika i morfologiâ). Beograd: ZUNS, 1969 (četvrto izdanje)]

Пипер, Предраг. Граматика руског језика: у поређењу са српском. Београд: Завет, 2005.

[Piper, Predrag. Gramatika ruskog jezika: u poređenju sa srpskom. Beograd: Zavet, 2005]

Пипер, Предраг, Иван Клајн. Нормативна граматика српског језика. Нови Сад: Матица српска, 2013.

[Piper, Predrag, Ivan Klajn. Normativna gramatika srpskog jezika. Novi Sad: Matica srpska, 2013]

Стевановић, Михаило. Савремени српскохрватски језик (Граматички системи и књижевнојезичка норма), у два тома: I, Фонетика и морфологија (Београд, 1964) и II, Синтакса (Београд, 1969).

[Stevanović, Mihailo. Savremeni srpskohrvatski jezik (Gramatički sistemi i književnojezička norma), u dva toma: I, Fonetika i morfologija (Beograd, 1964) i II, Sintaksa (Beograd, 1969)]

Станојчић, Живојин, Љубомир Поповић. Граматика српскога језика (уџбеник за I, II, III и IV разред средње школе). Београд: ЗУНС - Нови Сад: Завод за издавање уџбеника, 1992.

[Stanojčić, Živojin, Ljubomir Popović. Gramatika srpskoga jezika (udžbenik za I, II, III i IV razred srednje škole). Beograd: ZUNS - Novi Sad: Zavod za izdavanje udžbenika, 1992]

Klajn, Ivan. Gramatika srpskog jezika za strance. Beograd: ZUNS, 2006.

Maretic, Tomo. Gramatika i stilistika hrvatskoga ili srpskoga književnog jezika. Zagreb: Knjižara L. Hartmana (Kugli i Deutsch), 1899.

Marojević, Radmilo. Gramatika ruskog jezika (peto izdanje). Beograd: Zavod za udžbenike i nastavna sredstva, 1998.Skok, Petar. Etimologijski rječnik hrvatskoga ili srpskoga jezika I-IV. Zagreb: JAZU (1971-1973).

Tošović, Branko. Ruska gramatika u poređenju sa srpskohrvatskom. Sarajevo: Svjetlost, 1988. 
Александра Йович

\title{
СТАТУС ВОЗВРАТНЫХ МЕСТОИМЕНИЙ В ГРАММАТИКАХ РУССКОГО И СЕРБСКОГО ЯЗЫКОВ
}

\begin{abstract}
Резюме
В настоящей статье рассмотрен статус возвратных местоимений в грамматиках русского и сербского языков. Интерпретация и объём подкласса возвратных местоимений в грамматиках, а также грамматических учебниках и пособиях, являются довольно четким показателем основной ориентации авторов на семасиологический, традиционный, или ономасиологический подход. Хотя ценность рассматриваемых традиционных грамматик не оспаривается, указывается на преимущества грамматик ономасиологической ориентации с точки зрения лингвистической теории и практики.

Принимая во внимание функционально-семантическую, синтаксическую, морфологическую и словообразовательную разнородность (возвратных) местоименных слов, второй подход к их изучению и классификации представляется автору статьи оптимальным.

Ключевые слова: грамматика, местоимения/местоименные слова, семасиологическое описание ономасиологический подход.
\end{abstract}

